\title{
Sjælesørgerisk erfaringsnærhed i tre udvalgte gammeltestamentlige salmer
}

\author{
- et studium i brudfladen mellem bibelsk eksegese og \\ praktisk teologi ${ }^{1}$
}

\author{
Cand.theol., MPhil et MA. \\ Thomas Gudbergsen
}

\begin{abstract}
The study operates in the field between biblical exegesis and practical theology. The author seeks to unfold the tremendous resources for pastoral care to be found in the Psalms of the Old Testament. This is done through a detailed reading of the Hebrew manuscripts of three Psalms: Pss 13, 32 and 88. Four hermeneutical methods (identification, acceptance, contrast and expansion) are employed to show the value of the Psalms in pastoral care in two specific areas: terminal illness and prisons. As an approach to the Psalter in general the author develops a theory based on the ideas of Jewish philosopher Martin Buber. He makes the Psalm correspond to Buber's You through which the human $I$ may meet God, and in reverse, the medium through which God may express comfort and relief and illuminate the human $I$.
\end{abstract}

Keywords: Pastoral care (terminal illness and prison) - Old Testament biblical exegesis (Ps 13 - Ps 32 - Ps 88) - Martin Buber - hermeneutical models

\section{Indledning}

Bibelen rummer mængder af brugbart stof, men meget af det ligger gemt hen som en forladt kulturarv; og det er en skam! For det bibelske materiale emmer af livsvisdom og erfaringsnær teologi, som kan kaste meget af sig, hvis det bliver trukket frem i lyset og brugt på den rigtige måde. ${ }^{2}$ Jeg skal derfor i den foreliggende artikel argumentere

1. Artiklen er et redigeret uddrag af en afhandling på masteruddannelsen inden for sjælesorg og teologi udbudt på det Teologiske Fakultet i København. Afhandlingen bærer titlen Bibelbrug og bibelsyn i sjalesorgen - med sarligt henblik på identifikation ud fra de gammeltestamentlige salmer. Afhandlingen blev indleveret december 2014 og forsvaret januar 2015.

2. Jeg er mig naturligvis bevidst, at bibelske tekster bruges $i$ andre henseender i forvejen, $\mathrm{fx}$ indgår bibeltekster i diverse gudstjenester og kirkelige handlinger. Og det 
for, at de gammeltestamentlige salmer med stor fordel kan tages frem og anvendes i sjælesørgerisk øjemed.

Når de gammeltestamentlige salmer er særligt interessante i en sjælesørgerisk sammenhæng, så er det, fordi mennesket i særlig grad i Salmernes Bog taler til Gud ud fra erfaringer i livet og ud fra erfaringer med Gud. ${ }^{3}$ Man kan sige, at salmerne har en "evne til at reflektere menneskets emotionelle erfaring", som teologen Donald Capps også udtrykker det. ${ }^{4}$ Modsat for eksempel lovteksterne (meget af stoffet i Mosebøgerne), hvor Gud taler til mennesker, eller Paulus-teksterne, der forsøger at beskrive og systematisere troen og trosudsagn.

Med afsæt i klagesalmerne er religionspædagogen Ingo Baldermann også inde på, at salmerne og deres indhold er opstået som "Gebrauchstexte". ${ }^{5}$ Altså i den henseende at teksterne i udgangspunktet ikke er skrevet for at vejlede andre eller for at trøste andre. De er skrevet i her-og-nu-situationer for at trøste forfatteren selv, men er altså ikke desto mindre også anvendelige i dag som trøst og medvandringsmateriale for den nutidige læser. Således kan pastoralteolog Christian Möller eksempelvis også sige: "Trost in den Psalmen besteht hingegen darin, dem Menschen Worte auf die Zunge und Bilder für die Seele zu geben." ${ }^{\circ}$

Artiklens særegenhed består således $\mathrm{i}$ at bidrage til en dybere og mere omfattende forståelse af salmeteksterne i sammenhæng med den sjælesørgeriske praksis. Det sker i høj grad ved at vise, hvordan eksegesen med dens filologiske akribi og opmærksomhed på tekstens sproglige univers kan bringes i frugtbar samtale med sjælesorgens praktiske side og erfaringsnærhed. Undersøgelsens drivkraft er med andre ord både at lade den hebraiske salme tale dens eget sprog, men netop også med ønsket om at forbinde dette med en pastoralteologisk vinkel inspireret af forfatterens egne erfaringer som præst. Dermed dannes der bro mellem to discipliner: Den bibelske eksegese og den praktiske teologi. Et felt der bør kalde på generel øget opmærksomhed, eftersom begge lejre kan høste stor gavn deraf. Den praktiske

er for øvrigt ad den vej, at de fleste kristne møder de bibelske tekster (se fx således også Paul Ballard, "The Use of Scripture”, The Wiley Blackwell Companion to Practical Theology, red. Bonnie J. Miller-McLemore (Oxford: Wiley Blackwell 2014), 170. 3. Se endvidere Gordon Wenham, The Psalter Reclaimed-Praying and Praising with the Psalms (Illinois: Crossway 2013), 25-26.

4. Donald Capps, Forandringens mulighed-Essays om sjelesorg og praktisk teologi, red. og oversat af Troels Nørager (København: Forlaget Anis 1990), 38.

5. Ingo Baldermann, Ich werde nicht sterben, sondern leben - Die Psalmen als Gebrauchstexte (Neukirchen-Vluyn: Neukirchner Verlag 1990), 37.

6. Christian Möller, Kirche, die bei Trost ist-Plädoyer für eine seelsorgliche Kirche (Göttingen: Vandenhoeck \& Ruprecht 2005), 60.

7. Til det se fx også Ballard 2014, 164. 
sjælesorg for ikke at komme til at mangle teologisk og åndelig ballast. Den bibelske eksegese for ikke at glemme, hvad der er dens primære formål: At bidrage til en dybere og bredere forståelse af de bibelske tekster anvendt i praksis.

Jeg vælger i arbejdet at gå ud fra tre gammeltestamentlige salmer, hvis indhold jeg vil applicere på de sjælesørgeriske områder: Sygdom og fængsel. I afsnittet om sygdom tager jeg udgangspunkt i Sl 88, og i afsnittet om fængsel i Sl 13 og $32 .{ }^{8}$

Som overordnet indgangsvinkel til at tale om bibelbrug med henblik på de gammeltestamentlige salmer i det hele taget, vil jeg indlade mig med Martin Bubers grundlæggende ide om, at det menneskelige Jeg står i et relationelt forhold til et $D u$ uden for dets eget selv. Hvordan det mere præcist skal forstås i forhold til artiklens anliggende, skal jeg uddybe længere fremme. Ligesom jeg også der skal præsentere læseren for fire hermeneutiske modeller, der specifikt beskriver tilgangen og læsningen af den enkelte salme.

\section{Kort historisk udblik}

Mange hellige Fædre har lovprist og elsket Salmernes Bog frem for alle andre Bøger i Skriften (Martin Luther 1528). ${ }^{9}$

Salmernes Bog som sjælesørgerisk ressource er langt fra nyt. Allerede Jesus, da han hænger på korset, råber: "Min Gud, min Gud, hvorfor har du forladt mig?" (Matt 27,46) - en direkte henvisning til Sl 22,2; og lige før Jesus udånder, siger han jf. Luk 23,46: "Fader, i dine hænder overgiver jeg min ånd" - en genkaldelse af Sl 31,6. Også apostlen Paulus opfordrer til, at man synger salmerne i menighederne og opbygger hinanden på den måde (1 Kor 14,26; Ef 5,19 og Kol 3,16). Salmernes Bog er i øvrigt det mest citerede gammeltestamentlige skrift i Det Nye Testamente, hvilket også illustrerer på bedste vis, at salmernes indhold har udgjort en uvurderlig sjælesørgerisk reference også i den tidlige kristne kirke (Wenham 2013, 15).

8. I alle tilfælde er gengivelserne af teksterne baseret på min egen oversættelse af den hebraiske grundtekst i Biblia Hebraica Stuttgartensia. Hvor der ikke er tale om direkte oversættelse af hebraiske tekster, men hvor der fx er tale om henvisninger til andre skriftsteder, følger jeg versinddelingen i den autoriserede danske oversættelse af de bibelske skrifter Bibelen fra 1992.

9. Fra Martin Luthers anden fortale til Salmernes Bog således gengivet i Torben Christensen, Niels Nøjgaard, E. Thestrup Pedersen \& Regin Prenter, Bibelfortolkninger og pradikener, Luthers skrifter i udvalg 3 (Aarhus: Forlaget Aros 1980b), 34. 
Op igennem kirkehistorien er salmerne naturligvis også blevet benyttet, og som citatet, der indleder dette afsnit, klart indikerer, så skattede vor egen kirkes hovedreformator også værket højt. Luther kan sågar sige, at "Bibelens hele Sum" er sammenfattet i denne "lille Bog” (Christensen m.fl. 1980b, 35). En sådan udtalelse skal ses i lyset af, at Luther primært tolkede salmerne kristologisk, og deraf så han altså en sammenfatning af hele evangeliet i denne "lille Bog". ${ }^{10}$

Bladrer man i Den Danske Salmebog fra 2003, støder man på flere gendigtninger af de gammeltestamentlige salmer. Omtrent 40 salmer i salmebogen finder forlæg i Salmernes Bog i Det Gamle Testamente. Det er interessant, om end måske ikke så overraskende, at erfare, at Grundtvig lægger sig i spidsen med hele 15 gendigtninger af gammeltestamentlige salmer. To meget kendte salmer af Grundtvig fra salmebogen er: "Himlene, Herre, fortælle din ære" (DDS 392); en gendigtning af $\mathrm{Sl} 19$ og "Lovsynger Herren, min mund og mit indre!" (DDS 3); en gendigtning af Sl 103. Nævnes skal det også, at Luther tager udgangspunkt i de gammeltestamentelige salmer i sin salmedigtning. Tre salmer af Luther, hvor han tager afsæt i Salmernes Bog, er med i salmebogen: DDS 394/(Sl 12), 336/(Sl 46) og 496/(Sl 130). Brorson er også repræsenteret med tre salmer: DDS: 34/(S1 37), 714/ (S1 90) og 389/(Sl 119); og endelig en relativ ny salme. Det er Jørgen Michaelsens bidrag fra 1995: "Vort liv blev reddet" (DDS 339); en udlægning af Sl 124.

\section{En model for bibelbrugen}

Når man skal manøvrere med de gammeltestamentlige salmer i det sjælesørgeriske landskab, så er det som nævnt fordelagtigt at arbejde ud fra en bagvedliggende model. Til det er den østrigskfødte jødiske filosof Martin Bubers tanker i bogen Ich und Du velegnede. ${ }^{11}$ I bogen har Buber noget, han kalder "Grundwort", og der er to forskellige grundord. Det ene er ordrelationen "Ich-Es" (Jeg-det), og det andet er ordrelationen "Ich-Du" (Jeg-Du). Den første ordrelation beskriver forholdet til ting og til naturen. Den sidste ordrelation er den vigtigste, for den omhandler forholdet til andre mennesker og det åndelige. Buber siger om forholdet mellem Jeg'et og Du'et: "Es gibt kein Ich an

10. Se også John Steinar Jacobsens artikel, "Sjelesorg i Salmenes Bok - noen momenter”, Koinonia 2 (2000), 24-37 (29-30), hvor forfatteren også refererer til Luthers brug af de gammeltestamentlige salmer som sjælesørgerisk ressource i Luthers liv.

11. Martin Buber, Ich und Du (Berlin: Im Schocken Verlag 1936). 
sich, sondern nur das Ich des Grundworts Ich-Du" (Buber 1936, 10). På den måde får han sin grundlæggende pointe frem, at Jeg'et kun udfoldes fuldt ud i en gensidig relation til et andet $D u$.

\section{Buber, Gud og salmerne}

Martin Buber forholder sig også til Gud, og det gør han efter samme model, som han forholder sig til det andet $D u$. Det guddommelige $D u$ er dog større end det medmenneskelige $D u$ og er endvidere betegnet som evig tilstedeværelse. Men han forbinder alligevel de to $D u$ 'er og siger, at ethvert medmenneskeligt $D u$ er "ein Durchblick" til det evige $D u$ (89). Deraf er det også således hos Buber, at det evige $D u$ træder ind i verden igennem Jeg'ets relation til det menneskelige $D u$. At møde Gud er med andre ord, "nichts ausschalten, nichts dahinterlassen, [aber] “..." die Welt mit im Du begreifen, der Welt ihr Recht und ihre Wahrheit geben, nichts neben Gott, aber auch alles in ihm fassen, das ist vollkommne Beziehung" (93). ${ }^{12}$ Sammenfattende betyder det, at når man møder sin næste (Du'et) med alt omkring sig værende, sådan som det findes i verden, så optræder man deraf helt og fuldt i relation til Gud. Anderledes udtrykt er tankegangen, at hvis man møder og accepterer livet, som det er givet i og med mødet med ens næste, så møder man også den levende Gud: "Wer wahrhaft zur Welt ausgeht, gebt zu Gott aus" (111).

Hvordan kobler vi så denne Jeg-Du-forståelse sammen med brugen af de gammeltestamentlige salmer i sjælesorgen? Det gør vi ved at udvide Bubers grundlæggende tanker om Du'et i Jeg-Du-forholdet til at også at omfatte salmisternes digte på den måde, at salmen svarer til Bubers menneskelige $D u$. Når Jeg'et møder Du'et (salmen), og identificerer sig med de religiøse udtryk i digtet, kan det møde Gud. Vendt rundt kan det åndelige $D u(\mathrm{Gud})$ også meddele sig tilbage igen via salmen og tale til Jeg'et. På den måde gøres Bubers relationsteori anvendelig i forhold til en generel læsning af salmerne. Sat på formel: Mennesket kan igennem de gammeltestamentlige salmer finde udtryk for at tale til og med Gud (Menneske - salmer - Gud); men det bør også forstås den anden vej: Gud kan gennem de menneskelige udtryk i salmerne finde åben vej til menneskets indre (Gud - salmer - menneske).

12. De firkantede parenteser er min tilføjelse. 


\section{Forskellige hermeneutiske modeller}

Jeg skal i præsentationen af fire hermeneutisk modeller læne mig op ad den norske teolog og sjælesørger Tor Johan Grevbo, som i sin artikel, "Forkynnelse og bibelbruk i sjelesorgen" fra 2007 skitserer fire hermeneutiske tilgange. Grevbo fremstiller overvejende de fire tilgange som alternativer til hinanden. Jeg gør det samme i præsentationen her og refererer mestendels også til tilgangene i artiklen ud fra samme forståelse. I den praktiske sjælesorg vil dette dog ofte fremstå for enkelt i forhold til, at der mange gange er tale om, at modellerne også supplerer hinanden.

- Integration: Integrationsmodellen vil vise, at bibelske tekster og billeder kan hjælpe til at leve som et sammenhængende menneske trods modstridende indre følelser. ${ }^{13}$ Paulus taler for eksempel om, at han er trængt, men ikke indelukket, at han er fuld af tvivl, men ikke fortvivlet (2 Kor 4,8-12). Sl 88, som vi skal se på senere, lancerer også håb om, at end ikke døden kan rive mennesket ud af Guds hånd. Det vil sige, at teksten kan hjælpe den døende til at integrere den ellers uacceptable sygdom som en del af livet i den sidste tid.

- Ekspansion: Ekspansionsmodellen ønsker at pege på, at bibelske tekster kan give hjælp til at udvide troen og åndelige perspektiver (Grevbo 2013, 8). Eksempelvis bruger Paulus flere forskellige billeder på, hvad frelse er, og hver metafor kaster noget af sig og åbner derved flere døre ind til den samme Gud. ${ }^{14}$

- Kontrast: Kontrasttilgangen er et forsøg på at skabe en hermeneutisk nøgle, der kan åbne konfidentens øjne for, at Gud kan vende en dårlig situation til et nyt og godt udgangspunkt. S1 32,5 siger for eksempel: "Jeg fremlagde min synd for dig ... og du løftede min syndeskyld af skuldrene." Det kan altså handle om skyld, men det kan også blot dreje sig om, at konfidenten i efterrationaliseringens lys kan se, at det dårlige nu er blevet godt (jf. 1 Mos 50,20 og Es 38,17).

- Identifikation: Identifikationsmodellen er grundmodellen. Nærmere forklaret i sammenhæng med de gammeltestamentlige salmer

13. Tor Johan Grevbo, "Bruk av bibel i sjelesorgen" (powerpoint-slides fra 29. august 2013) (København: Masterutdannelsen innenfor sjelesorg, det Teologiske Fakultet), 8. "Sidetal" 8 refererer til ottende slide i Grevbos powerpoint-præsentation.

14. Tor Johan Grevbo, "Forkynnelse og bibelbruk i sjelesorgen", HPT 1 (2007), 30-44 (39). 
skal det forstås sådan, at når den syge ved læsning af en salme integrerer sin sygdom som en del af tilværelsen, så er det logisk set, fordi vedkommende også kan identificere sig med de udtryk og følelser, der beskrives i salmeteksterne. Det samme kan siges i henhold til både kontrastmodellen og ekspansionsmodellen.

Vi skal nu gå over til at arbejde konkret med tre udvalgte salmer fra Det Gamle Testamente og applicere disses indhold på to specifikke sjælesørgeriske kerneområder: Sjælesorg over for terminalt syge og sjælesorg over for den fængslede.

\section{Sygdom}

Når man er syg, ønsker man at blive rask, og er man livstruende syg, ønsker man det endnu mere. Men hvad gør man, når det ikke er sandsynligt, at ens sygdom kan kureres? Her er vi i Vesten særdeles udfordret af det faktum, at vi er så ureflekteret hengivne til den tankegang, at livet leves kontinuerligt fra A til B - uden væsentlige hindringer. ${ }^{15}$ Ser vi på ikke-vestlige kulturer i dag, for eksempel den jødiske, så er måden at forstå tingene på anderledes. Ifølge jødisk livsfilosofi er livet forstået som større end lidelsen, og sygdom og lidelse bliver derfor betragtet som en integreret del af tilværelsen. ${ }^{16}$ Derfor er det heller ikke selve livsgrundlaget, der trues, når Herren gennem profeten Esajas siger, at Gud også er den, der skaber mørke og ulykke i livet (Es 45,7). Livsgrundlaget er ikke materiel og legemlig fremgang, men derimod det at være $\mathrm{i}$ Herrens hånd. Lidelsen er ikke $\mathrm{af}$ den grund noget mål i sig selv i gammeltestamentlig tænkning og skal for så vidt bekæmpes. Men det er samtidig noget mennesket må forsone sig med, da det er en uundgåelig del af livet.

Når mennesket mødes af uoprettelig modgang på den ene eller den anden måde, så er det bedste sjælesørgeriske råd, at man må forholde sig til det, som det er. Selvfølgelig har man lov at ønske, at blive rask; og man skal selvsagt opsøge professionel hjælp for om muligt at blive kureret for sin sygdom eller lidelse. Men hvis man ikke kan blive det, så må den enkelte med tiden acceptere sygdommen og sige: "Mit liv er ikke forkert og spildt nu, men det er anderledes, og jeg skal forholde mig til mig selv og mit liv på en ny måde.” Denne værdiom-

15. Lone Vesterdal, Nedenom og hjem - Perspektiver på tab og tro (København: Unitas Forlag 2014), 121.

16. Matthew B. Schwartz \& Kalman J. Kaplan, Biblical Stories for Psychotherapy and Counseling - A Sourcebook (Binghamton: Haworth Pastoral Press 2004), 5. 
vending er svær, men er en helbredelse i sig selv. Det er at leve i lyset inde i mørket, som Klara Myhre også argumenterer for det netop med afsæt i Salmernes Bog. ${ }^{17}$

\section{Sl 88 - med døden for øje}

Salmernes Bog indeholder 150 salmer i alt, og cirka en tredjedel af dem er såkaldte klagesalmer. Disse er skrevet af mennesker, der står med lidelsen og trætheden som udgangspunkt for næste skridt, og det er derfor af stor sjælesørgerisk betydning, at de findes, for mennesker kan også i dag identificere sig med dem. De fleste af klagesalmerne ender dog med en lovprisning til Gud. Men for den uhelbredeligt syge og for den, der af andre grunde har opgivet alt håb og livsmod, kan det være svært at identificere sig med, at det hele slutter med en lovprisning. Ud af de omkring 50 klagesalmer findes fire salmer, som ikke slutter oppe, men ender stemningsmæssigt nede. Det er Sl 39, 88, 120 og til dels Sl 143. Jeg skal i det følgende med udblik til det terminalt syge menneskes situation analysere udvalgte vers af Sl 88 . Her er identifikationsmulighed for den, for hvem alt håb er ude, og alt er mørkt.

v. 5 Jeg regner mig selv blandt dem, der stiger ned i graven; jeg er blevet som en mand uden kraft. v. 6 Blandt de døde er jeg fri, ligesom de slagne er det, de der ligger i graven; jeg er blandt dem, du ikke længere husker. De er afskåret fra din hånd. v. 7 Du har sat mig i den dybeste grav i det mørkeste dyb.

... og den slutter i samme tone ...

v. 19 Den elskede og vennen har du været årsag til ikke er hos mig; de som kender mig er i mørket.

Det er interessant at se så meget magt over sproget, der ligger i oversættelsen. Den autoriserede danske udgave af Bibelen, siger: "Blandt de døde er jeg spærret ind" (v. 6). Det er noget andet end at være fri blandt de døde, som min oversættelse lægger op til. Men ordet der er

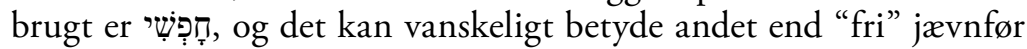
betydningen frihed fra slaveri eller lignende. ${ }^{18}$ Af det tekstkritiske apparat kan man også se, at der er søgt tekstmæssige forbedringer med verbet bestående af de samme konsonanter חiפ. Udsagnsordet bety-

17. Klara Myhre, "Leve i lyset med sitt mørke - Sjelesørgeriske motiv fra Det gamle testamentes klagesalmer", TfS 2-3 (1994), 149-160 (159).

18. Francis Brown, Samuel R. Driver \& Charles Briggs, The Brown-Driver-Briggs Hebrew and English Lexicon (Massachusetts: Hendrickson Publishers 1906), 344. 
der "at søge", og er i det tekstkritiske apparat gengivet i den hebraiske form pu'al, hvilket får en forstærket passiv/refleksiv betydning frem, så der kommer til at stå: "Blandt de døde er jeg blevet ledt efter og fundet". Det er igen noget andet end at være fri. Den engelske standardoversættelse af de bibelske skrifter (ESV) er tæt på originalteksten, når den siger: "like one set loose among the dead". Og hvorfor ikke bibeholde denne betydning, for den kommer ofte tæt på virkelighedens verden. Når et mennesker lider af smerter og er terminalt sygt, så vil ganske mange føle, at de i deres nuværende situation allerede er på vej ned i graven og betragte døden som en frisættelse, fordi døden vil forløse for smerter og give hvile.

\section{Identifikation og integration}

Salmen er derved en medvandrings-salme til mennesket uden håb. Den kan også siges at være et spejl af et andet menneskes tros- eller livsbekendelse til Gud. Her er der en, der som jeg heller ikke kan forstå verdens, og for den sags skyld, Guds underlige måde at agere på. Identifikationen gør dermed, at den lidende ikke er helt alene. Donald Capps taler sågar om, at det hymniske sprog gør, at teksterne er åbenbarende, fordi det giver rum for følelser, der rækker ud over dagligdagsoplevelsen (Capps 1990, 27). ${ }^{19}$ Det baner vejen for at sige, at hvis den syge kan identificere sig med salmistens udtryk, så nærmer vi os også Grevbos integrationsmodel, ved det at den andens ord skaber en grad af accept i den lidende. Det gør, at vedkommende bedre kan integrere sig med det svære og lettere leve med det. Og måske netop i det optimist-produktive samfund er Sl 88 et fund. Mennesker siger tit til hinanden: 'Det skal nok gå, du bliver rask igen... Men det er langt fra, at det altid går sådan, og straks salmen slog over i det positive, ville identifikationsmuligheden ophøre for den terminalt syge, for salmen ville derved bevæge sig væk fra patientens virkelighed. Gud erfares ikke som god i situationen, langt snarere kan Gud ligefrem føles som en fjende (Baldermann 1990, 102). Derfor er Sl 88 i høj grad relevant for den meget syge.

\section{I dialog med Gud}

Teologen og gammeltestamentleren Walter Brueggemann har en interessant vinkel på tingene, når han taler $\mathrm{om}$, at når den lidende læser eller beder en salme, så føles det som om "this psalm is affected by our experience” (Brueggemann 2007, 10). Brueggemann bruger det

19. Således bemærker Grevbo det samme (Grevbo 2007, 42), ligesom det også hos Walter Brueggemann er en hovedtese flere steder, at sproget i sig selv er frigørende; se fx kap. 3, "Language appropriate to place" i hans Praying the Psalms - Engaging Scripture and the Life of the Spirit (Eugene: Wipf \& Stock Publishers 2007), 29-41. 
til at sige, at teksterne vidner om en åben og dialogisk Gud, der lader sig påvirke af menneskers klage til ham (Brueggemann 2007, xvixvii). ${ }^{20}$ Sproget i salmerne udtrykker altså ikke en bekendelse i gængs forstand. Det går også an at vende det om og sige, at sproget er dialogisk: 'Hør her, Gud, det gør ondt - så hjælp mig dog!'. Men den slags udtryk har "kristelig snillisme" i vid udstrækning set bort fra, fordi det ikke passer ind i det dannede kirkeliv (Myhre 1994, 151). Men det er en skam, for klagen er forløsende i sig selv og første skridt mod en eventuel forandring. Den danske teolog Jakob Wolf er akkurat inde på samme tankegang, når han taler om, at vendingen fra klage til forløsning alene kan ske derved, at man klager, for i klagen ligger allerede et udtryk for tillid derved, at der klages til nogen. ${ }^{21}$

Som eksempel på klage/anklage til Gud, kan man læse følgende i gæstebogen fra Rigshospitalets kirke: "Du kan ikke være bekendt, hvis du tager ham fra mig “...”. Han er min og du har bare at sørge for at han bliver hos mig i mange år endnu". ${ }^{22}$ Det er et tilfælde, hvor en forælder er ved at miste sit barn. Man kan igen spørge, om det er kristeligt passende at tale sådan til Gud? Det mener jeg, det bør være, for det er nu engang sådan barnets far har brug for at udtrykke sig i situationen. Gud møder ikke en påtaget lovprisning eller bøn her. Gud møder virkeligheden. Det er dermed samtidig en bekendelse til Gud. Det "er uttrykk for den tapreste tro", som Øyvind Eide udtrykker det (Eide 1988, 30).

Derved drager vi også paralleller til Walter Brueggemanns overordnede forståelse af forholdet mellem Gud og mennesker: "human persons are grounded in Another who initiates personhood and who stays bound to persons in loyal ways for their well-being". ${ }^{23}$ Brueggemanns tanke er, at når mennesket er forankret i en pagt med Gud, så hører mennesket uløseligt hjemme der, og så er det følgelig også naturligt, at mennesket klager, når det gør ondt. Jakob Wolf siger det samme: "I afmagten og vreden anerkender vi, at vi er børn i forhold til Gud. Vi er ikke lige så kloge som Gud; men derfor har vi også ret til at skrige op over for Gud, som børn, der er i nød, skriger op over

20. Således også Hanne Løland, "Mitt liv er kommet nær dødsriket - Klage i Det gamle testamentet og i dag", HPT 1 (2008), 36-47 (38).

21. Jakob Wolf, Jobs Tårer-Om Gud og det onde (København: Forlaget Anis 2009), 41. Se også Løland 2008, 36-37 og Øyvind Eide, "Fra klagesang til lovsang - Tanker om sjelesorg i møte med Bibelens salmer”, TfS 3 (1988), 29-36 (31).

22. Christian Busch, "Store ord, små ord og trængte ord i sjælesorgen" (powerpointslides fra 11. juni 2014) (Hillerød: Helsingør stiftskonvent, Grundtvigs Højskole), 13. "Sidetal" 13 refererer til trettende slide i Buschs powerpoint-præsentation.

23. Walter Brueggemann, The Psalms and the Life of Faith, red. Patrick D. Miller (Minneapolis: Fortress Press 1995), 151. 
for deres forældre" (Wolf 2009, 82). ${ }^{24} \mathrm{Vi}$ kan føje til og sige, at den gammeltestamentlige salme er kommunikationsmidlet i pagten derved, at den lidende må tiltale Gud gennem salmen, og må forvente, at Gud vender tilbage igen ad samme vej for eksempel ved at afstedkomme en følelse af, at den bedendes klage/anklage er blevet hørt.

\section{I dine hander, Herre Gud}

I de vers som har været omdrejningspunktet for arbejdet med S1 88 indtil nu (v. 5-7.19), udtrykkes der som vist ikke meget håb, men Gud er dog ikke helt fraværende. Digteren underforstår hele tiden, at Gud er til stede i lidelsen: " $D u$ har sat mig i den dybeste grav i det mørkeste dyb" (v. 7). Midt i meningsløsheden tales der direkte til Gud som værende til stede bag det hele. Salmen starter også med at sige: "Jahve, min frelses Gud, om dagen skriger jeg [til dig] om natten er jeg foran dig." ${ }^{25}$ Det er udtryk for en meget direkte Jeg-Du-konstellation. Salmisten er på den ene side helt modløs og dybt nedtrykt, men på den anden side er alt ikke tabt, for den lidende råber stadig til Gud og er derved i en relation til ham.

Det får Gud til at opleves barsk og ondskabsfuld, for han helbreder ikke, skønt han kunne, og han tillader endda smerterne. Gud fremstår derfor usympatisk, når han tillader lidelsen. Men han er der dog, og den lidende er ikke i frit fald. Uden Gud var lidelsen trods alt mere meningsløs. På den måde bliver byrden ikke bedst beskrevet som en fjende, men som en uløselig gåde, ${ }^{26}$ som livet - og Gud ikke giver noget svar på. Gud dannede mig af støvet, og nu gør han mig til støv igen (jf. 1 Mos 3,19; Job 10,8-9); men så er jeg dog i og med det - trods alt - stadig en proces $i$ hans hånd. Man kan med andre ord teoretisk beskrive det således: Det at råbe og bede til Gud, når alt det, der normalt definerer mig, er borte, bliver en søgen efter en ny identitet, sådan som teologen Christoph Hinz også udtrykker det. ${ }^{27}$

I salmens begyndelse er der også den fine skelnen mellem at være den aktive, den der råber, og den passive, den der hviler: "Jahve, min frelses Gud, om dagen skriger jeg, om natten er jeg foran dig" (v. 2). Denne oversættelse afviger også fra den autoriserede oversættelse: "Dag og nat råber jeg til dig." Men den hebraiske tekst lægger op til

24. Jakob Wolf gør i bogen Jobs Tårer i det hele taget op med samtlige teodicéargumenter. I stedet argumenterer han for, at mennesket netop må gå til Gud med vreden og afmagten. Det er den eneste måde at opretholde et ægte forhold til Gud på, når livet gør ondt.

25. De firkantede parenteser er min tilføjelse.

26. Leif Andersen, Gud, hvorfor sover du? - Tro og protest i lidelsen (Fredericia: Lohses Forlag 1987), 13.

27. Christoph Hinz, Glimt af håb - Gammeltestamentlige salmer - en trøst i sygdom, oversat af Inge \& Helge K. Nielsen (København: Unitas Forlag 1995), 13. 
den passive position foran Guds ansigt om natten. ${ }^{28}$ Når jeg er vågen, så tøver jeg ikke med at brokke mig og klage, men når du under mig lidt hvile, Gud, så er jeg blot foran dig (긱). Selvom dette, sammen med den omtalte Guds-tilstedeværelse i lidelsen i det forrige, er ord for et indirekte håb, så kan man ikke sige, at det er udtryk for håbet om at blive befriet fra lidelsen; den overordnede kontekst i salmen siger noget andet. Det er snarere udtryk for tilliden til Guds tilstedeværelse i det onde og troen på, at mennesket ikke kun har sig selv og verden at falde tilbage på, men netop også har muligheden for at falde tilbage på Gud (Busch 2014, 31).

På den måde finder vi en tekst i Sl 88, som står mål med de sværeste situationer, mennesket kan komme i, og som man som sjælesørger kan komme ud for at møde mennesker i. Salmen minder os nådesløst om, at livet og tingene ikke altid har "happy endings".

Og med det skal vi bevæge os over i et andet vigtig sjælesørgerisk tema, nemlig det at øve sjælesorg overfor indsatte i et fængsel.

\section{Fængsel}

For hele det gammeltestamentlige psalter gælder det, at det står i lyset af Sl 1's bekendelse: At den der vandrer efter ugudeliges råd; ham går det dårligt (S1 1,4-6), mens den der grunder på Herrens livsvejledning (budene); ham går det godt (Sl 1,1-3). ${ }^{29}$ Forstået på den måde, at den der søger Herren, er som et træ ved bækken (Sl 1,3) - også den lidende. Trærøddernes adgang til vandet i bækken er ikke frisættelse fra lidelse, men tilliden til Herrens nærvær i det svære, som er lægende i sig selv.

Når man kommer i fængsel, ${ }^{30}$ er det første man tænker på ikke Salmernes Bog i Det Gamle Testamente. Men ovenstående syn på salmerne er alligevel konstruktivt, også i fængslet, fordi Herrens lov i bred betydning skal forstås som vejen til det gode liv. Ordet lov, som er oversættelsen af det hebraiske תָּ (torah) betyder "vejledning" eller "instruktion" (Brown, Driver \& Briggs 1906, 435). At budene peger i retning af det gode liv, fremgår allerede af den sammenhæng,

28. Således også Marvin E. Tate, Psalms 51-100 (Nashville: Nelson Reference \& Electronic 1990), 393. Se evt. også Robert Alter, The Book of Psalms (London: W. W. Norton \& Company 2007), 308 for en lidt varierende læsning.

29. Se hertil Wenham 2013, 110 og 116-118; og som yderligere teksteksempler, se Sl 26; 36 og 112.

30. Når jeg beskriver situationer fra fængslet, tager jeg afsæt i min egen erfaring fra tiden som fængselspræst på løntilskud i Vestre Fængsel i København. 
instruktionerne er talt ind i. Buddet om at ære ens forældre er for eksempel specifikt givet, for at man skal have et langt liv på jorden

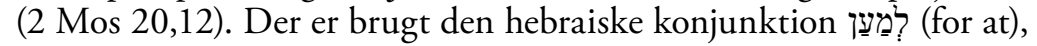
som netop betegner en hensigt på baggrund af det forudgående i sætningen. ${ }^{31}$ Således taler Moses også til folket før indvandringen i det forjættede land og siger: "Gør hvad der er ret og godt i Jahves øjne, for at (לְֵַ) det må gå dig godt" (5 Mos 6,18; sammenlign også: 5 Mos 4,$40 ; 5,16 ; 12,25 ; 22,7$ og 24,19). Ligeledes, når Gud forbyder drab (2 Mos 20,13), så giver det mening, også for den der har slået et andet menneske ihjel og ender i fængsel, for det er ikke vejen til noget godt på den lange bane.

Men før en indsat kan komme frem til et fornyende udgangspunkt for livet videre frem, må der være plads til klagen. For det gør ondt at komme i fængsel; særligt at komme i et arresthus, hvor ens skæbne er uvis, indtil dommeren afgør ens sag. I den mellemliggende periode oplever mange symptomer på angst og depression. Miljøet er råt, og der hersker et strengt hierarki blandt de indsatte. Men bag den låste celledør får tankerne frit løb, og mange af de tanker får fængselspræsten lov at lytte til, og man kan ligefrem som præst få lov at være aggressions- og frustrationsafladende. Det er også i nogle af disse situationer, at klagesalmerne fra Det Gamle Testamente kan være til god hjælp for den indsatte. På vejen videre skal vi tage udgangspunkt i Sl 13, som giver luft for klagen.

\section{Sl 13 - klage}

v. 2 Hvor længe, Jahve, vil du glemme mig; - for bestandigt! Hvor længe
vil du skjule dit ansigt for mig? v. 3 Hvor længe skal jeg lægge planer
for mit liv? sorg [er] i mit inderste dagligt! Hvor længe skal min fjende
triumfere over mig? v. 4 Se! Svar mig, Jahve min Gud; oplys mine øjne,
for at jeg ikke skal sove ind i døden. v. 5 For at min fjende ikke skal sige:
"Jeg har sejret over ham" [og] mine uvenner juble, fordi jeg er bragt ud
af balance. ${ }^{32}$

Den klagende berører her mange temaer, som den fængslede kan identificere sig med, og jeg skal liste nogle af dem op.

- At vare overset: Oplevelsen af at være overset og overhørt af andre fylder meget for mange indsatte. Man kan føle sig overset af fængselspersonalet, det juridiske system og måske også af folk uden for

31. Christo H. J. Van der Merwe, Jackie A. Naudé \& Jan H. Kroeze, A Biblical Hebrew Reference Grammar (Sheffield: Sheffield Academic Press 2002), 304.

32. De firkantede parenteser er min tilføjelse. 
murene. En syg person vil naturligt opleve meget medfølelse og omsorg fra pårørende, men sådan er det langt fra altid for en kriminel. Grundholdningen er oftest den, at vedkommende får, som han fortjener. Over for det er det præstens vigtigste opgave at forsøge at møde mennesket bag forbrydelsen og vise omsorg; og fængselspræsten vil i mange tilfælde være den eneste, der får lov at se noget godt og smukt i mennesket, der har begået en forbrydelse.

Ind i sammenhængen har Martin Buber en interessant pointe, når han siger: "Wer mit dem ganzen Wesen zu seinem Du ausgeht [det menneskelige $D u$ ] und alles Weltwesen ihm zuträgt, findet ihn, den man nicht suchen kann" (Buber 1936, 93). ${ }^{33}$ Bubers tanke er, at når vi møder det andet menneske med alt, hvad vi selv er og har, så finder vi ad den vej Den Guddommelige igennem den anden, som vi også tidligere var inde på det. På den måde er man som præst for det første ydmygt til stede i egen skrøbelighed for den indsatte, men man må også se for sig, at Gud træder frem i den anden i skikkelse af den medlidende trøster. ${ }^{34}$

- Ydmygelsen og vrede: Når man ender i fængsel, er der meget ofte også andre, der burde have været samme sted; de har måske sågar været direkte eller indirekte årsag til, at man selv er i fængsel nu. Så martres man ved, at de slipper fri, og det afstedkommer magtesløshed og vrede. Og vreden kan sagtens blive så gennemtrængende, at der kan blive tale om en parallel til eksemplet med salmisten, der ønsker, at modstanderens børn skal knuses mod klippen og dø (Sl 137,9). Det skal i sammenhængen her betones, at vel kan sådanne følelser være forståelige hos den indsatte, og de skal have lov at finde afløb. For eksempel ved at spejle sig i salmistens udtryk. Men de hævngerrige tendenser i salmen må naturligvis ikke ses som legitim bevæggrund for selv at udføre voldelige handlinger. Pastoralteologen Peter Bukowski peger akkurat også på, at hævnsalmerne kan være en velvalgt måde at imødekomme stærkt negative følelser på, fordi hævnsalmen som noget af det eneste har rum for disse sider af det menneskelige følelsesregister. ${ }^{35}$

- At dø indvendig: I v. 4 råber den nedslåede: "Vågn op, Gud - hvis $\mathrm{du}$ er der! Giv mine øjne lys og glans, for jeg er ellers ved at dø". Det

33. De firkantede parenteser er min tilføjelse.

34. Til det se evt. også Karen-Sidsel Solberg, "Lidelse og mening i Bibelens lys", Koinonia 2 (2000), 6-12 (10).

35. Peter Bukowski, Die Bibel ins Gespräch bringen - Erwägungen zu einer Grundfrage der Seelsorge (Neukirchener: Neukirchener Verlag 1994), 74. 
gør noget ved et menneske at blive låst inde $\mathrm{i}$ en lille celle stort set døgnet rundt. Man kan fysisk se på folk, at de taber glansen i øjnene, og der bliver grædt mange tårer, og ikke få forsøger, eller truer i hvert fald med, at tage deres eget liv. Mange indsatte spørger selvsagt, hvorfor lige mig; der er så mange andre, der er værre end jeg!? Lidelsen og magtesløsheden, og længslen og råbet om at komme ud af trængslerne, bliver derved et gelænder, man automatisk støtter sig til (Hinz 1995, 30). Målet for fængselspræsten er her at være lyttende og forsøge at lade "gelænderet", som den fængslede holder sig til, gå i retning af Gud og trøsten hos ham. Det kan ske ved hjælp af samtale, bøn og måske ved at læse en salme, som kan sætte ord på frustrationen og bitterheden.

S1 13 har altså, som vi også så det med Sl 88, et primærformål i at vække konfidentens følelser, altså i at være identifikationsskabende. Man kan endvidere også sige, at når en person beder salmen, og benytter sig af det kraftfulde billedsprog, som salmisten bruger, så opnår man også en udefrakommende stemme, som bringer noget nyt og budskabsbærende ind i det forstemte sind (Capps 1990, 33). Dermed er der også noget ekspansion over salmen, altså noget der udvider det menneskelige selverkendelsesrepertoire: "Oplys mine øjne [Jahve]". Underforstået: "Lad dit åsyns glans oplyse mig, så jeg ser klarere".

Dermed har vi endnu engang med udgangspunkt i Buber set, at den enkelte igennem salmerne kan finde udtryk for at tale til Gud (Menneske - salmer - Gud); men også at det kan forstås den anden vej: Gud kan gennem de menneskelige udtryk i salmerne finde vej til mennesket (Gud - salmer - menneske).

I det næste afsnit, hvor vi tager udgangspunkt i S1 32, skal vi se, at kontrastmodellen bliver meget tydelig.

\section{Sl 32 - selvransagelse}

I fængslet vil der være tilfælde, hvor det også giver mening at udfordre den indsatte til at grunde på Herrens lov i betydningen at stræbe efter et bedre liv. I konteksten skal det i første omgang forstås som det at blive oplyst om sig selv, og om hvor man er på vej hen med sit liv; ligesom salmisten, der beder: "Ransag mig, Gud, og kend mit inderste; prøv mig og kend mine tanker. Se efter, om jeg er på smertens vej, og før mig på den holdbare vej" (Sl 139,23-24). Jeg skal yderligere i det følgende også tage afsæt i Brueggemanns formulering: "We have in the Psalms resources for helping persons ... evoke in their lives new 
worlds of well-being” (Brueggemann 1995, 31). ${ }^{36}$ Sl 32 har et sådant livsbekræftende billede på fornyelsen.

Lykkelig den hvis overtrædelse er løftet [af skuldrene], hvis synd er dækket.

v. 2 Lykkeligt det menneske, som Herren ikke tilregner skyld, og i hvis ånd der ikke er svig. ${ }^{37}$

v. 3 Da jeg var tavs, ældedes mine knogler - i min stønnen dagen lang. v. 4 For dag og nat hvilede din hånd tungt på mig; min livssaft tørrede ind i min feberhede - (sela).

v. 5 Jeg fremlagde min synd for dig, og jeg skjulte ikke min skyld. Jeg sagde: "Jeg vil være ærlig over for mig selv om mine overtrædelser mod Jahve; og du løftede min syndeskyld (af skuldrene)" - (sela).

Her er det meget tydeligt, at det er den totale nedrivning af forsvarsværkerne i tilværelsen, der er vejen til fornyelse. Det kan jævnføres med freudianske termer, der siger, at når fortrængningerne af virkeligheden opgives, så skabes der frirum, der kan italesætte det som fylder indeni; og samtidig kan det at sætte ord på det indestængte føre til bevidstgørelse af endnu flere fortrængninger. Dog er det vigtigt, som Luther i sin Lille Katekismus nævner det i indledningen til skriftemålet, at konfidenten kun skal bekende det over for skriftefaderen, som vedkommende reelt har gjort og føler sig skyldig i. Den angrende skal ikke bevidst forsøge at tale noget frem i sig selv, som han eller hun i virkeligheden ingen skyld har i. ${ }^{38}$ Når det er sagt, så er det ikke desto mindre afgørende at stå ved sin ugerning, for "det er ikke mulig å bli fri fra skyld uten å innrømme skyld”, som teolog og tidligere fængselspræst Paul Leer-Salvesen udtrykker det. Og han fortsætter i samme åndedrag og siger: "Gjerningspersonen ... må gjennom den [skylden] ... Ellers ligger den ubearbeidede skylden der og holder dem fast i det som hendte og preger livene deres." ${ }^{99}$ Skylden må altså tages bort, ellers tærer den mennesket op indefra og bliver højeste gear i ældningsprocessen, som salmisten malende beskriver det: "Da jeg var tavs, ældedes mine knogler" (v. 3).

36. Se evt. også hertil Brueggemann 2007, 17-41.

37. Her siger den græske oversættelse Septuaginta: "og i hvis mund/tale ( $\sigma \tau o ́ \mu \alpha)$ der ikke er svig".

38. Torben Christensen, Niels Nøjgaard, E. Thestrup Pedersen \& Regin Prenter, Skrifter om Kirke og Gudstjeneste, Luthers skrifter i udvalg 2 (Århus: Forlaget Aros 1980(a)), 257.

39. Paul Leer-Salvesen, Min skyld (Oslo: Verbum 2002), 32. De firkantede parenteser er min tilføjelse. 


\section{Lette skuldre}

Når den indsatte betror sig til præsten, så er det som at få løftet en byrde af skuldrene. Der er netop brugt verbet נָָ på hebraisk, som betyder "løfte", "bære" eller "tage af" (Brown, Driver \& Briggs 1906, 669). Den indsatte er nu en mand med lette skuldre og ikke tyngede skuldre, og der er skabt stor kontrast i forhold til tidligere. Man kan derfor også sige, at ved at stille skarpt på sproget i salmen, får vi tegnet et nyt positur af den indsatte i dennes bevidsthed (Brueggemann 2007, 29). Opnår man som præst nær tillid til den indsatte, kan man i kølvandet på en fortrolig bekendelse spørge om vedkommende har mod på også at bede om tilgivelse hos Gud. Det er den ultimative frihed og den frihed, som er centrum i Sl 32.

I det følgende skal jeg skildre en oplevelse, som lettere omskrevet bygger på en virkelig hændelse. Historien handler om, at jeg talte meget med en indsat i Vestre Fængsel, som sad inde for en voldssag; - en lille en af slagsen, hvis man spurgte Fred. ${ }^{40} \mathrm{I}$ det hele taget negligerede Fred, hvad han havde gjort og følte sig selv konstant uretfærdigt behandlet af "systemet". ${ }^{41}$ Efter nogle gange med fortrolige samtaler, hvor jeg flere gange spurgte ind til episodens omstændigheder, samtidig med at Fred fortsat hang fast i en overfladisk og ligegyldig tilgang til sin egen forbrydelse, brød jeg ind og sagde: "Du er ikke uskyldig, Fred, og lige meget om du bliver frikendt i retten eller ej, så får du aldrig god samvittighed igen, før du får sagt undskyld for det, du har gjort forkert!" Det endte med, efter nogen tid, at Fred gennem politiet fik afleveret et brev til den forurettede, hvori han sagde undskyld. Han havde det derefter ligesom konfidenten i S1 32. Først nu var han fri! - og så blev han oven i købet løsladt noget tid efter, og så var han også fri i juridisk forstand.

Efter indrømmelsen var der skabt stor kontrast i forhold til tidligere. Man kan sige med tilbageblik på Buber, at skyldsbevidstheden opstod, idet Fred fjernede sit forsvar og indså, at han havde krænket et andet $D u$, sådan som Leer-Salvesen også taler om det (Leer-Salvesen 2002, 11). Der kom "ansigt" på den krænkede, ved at fængselspræsten forsøgte at få Fred til fortælle historien om voldsepisoden flere gange. Langsomt blev det klart for ham, at det ikke var noget det, han havde gennembanket, men et $D u$. Det beskriver godt, hvilken forskel det gør, om man betragter dem, man færdes i blandt som ligeværdige medmennesker eller blot som tilfældige forbipasserende, der er til for den enkeltes egen skyld.

40. Fred er et opdigtet navn.

41. For Fred en samlebetegnelse for samfund, politi og fængselsvæsen. 
Med det skal fængselsdelen rundes af med at fastslå, at der i Salmernes Bog også er materiale, der taler ind i den fængsledes situation. Der er tekster, der kan være identifikationsskabende (Sl 13), og tekster, der udfordrer til at gå selvransagelsens vej (Sl 32), og dermed blive kontrastskabende og fornyende. ${ }^{42}$ I henhold til netop det kontrastskabende lander vi også, som vi indledte dette afsnit ved, at Herrens torah er givet for det gode livs skyld. Vejen til et bedre liv går via en selvransagelsesproces, der tager livtag med det onde og det, der kræver indrømmelse; og ad den vej skabes der lys fremadrettet (sammenlign også S1 19,8-11; 34,13-15).

\section{Opsamling}

Sammenfattende kan hermed siges, at artiklen metodemæssigt bevæger sig på tre niveauer. Martin Bubers Jeg-Du-relationsteori opererer som filosofisk bagvedliggende tolkningsmodel for en general tilgang til salmerne, hvilket kan rammes ind af den kiastiske struktur, som vi har set i artiklen nogle gange: Menneske - salme - Gud og Gud salme - menneske.

Dernæst anvendes Grevbos fire hermeneutiske modeller tematisk til at kaste lys over de enkelte salmer. Vi har set tekster, der er til at identificere sig med, når man som menneske oplever modgang $\mathrm{i}$ livet. Det at salmerne har ord for meget svære livssituationer gør, at konfidenten selv får ord at udtrykke sig med; det er i sig selv forløsende. For den døende kommer livet ikke tilbage, og salmens ord kan da være trøstende og hjælpe til, at den syge integrerer og accepterer sygdommen som en del af den tilværelse, der er tilbage at leve i. I afsnittet om sjælesorg i fængslet var vi inde på, at for den kriminelle kan det at læse, at skylden blev løftet af skuldrene på salmisten være inspiration til selv at gå ind i en lignende proces, og da kan nye muligheder åbne sig (kontrast og ekspansion).

Endelig har det filologiske greb om grundteksten vist, at på det rent sproglige niveau ligger der mange nuancer gemt, som bringer salmernes erfaringspotentiale endnu tættere på den sjælesørgeriske virkelighed. Særligt det sidste er som antydet i indledningen med til at føre det eksegetiske fag tættere sammen med den pastorale praksis. En teologisk disciplin og et forskningsfelt der med stor fordel kan opdyrkes mere til stor berigelse for begge lejre, og dermed for kirken.

42. Se også Sl 51, det er også et meget godt eksempel. 